\title{
The Activity and Specificity of the Proline Permease in Wild-type and Analogue-resistant Strains of Escherichia coli
}

\author{
By H. TRISTRAM AND STELLA NEALE \\ Department of Botany, University College London, W.C. I, and \\ Courtauld Institute of Biochemistry, Middlesex Hospital, London, W. I
}

(Accepted for publication 5 July 1967)

\begin{abstract}
SUMMARY
The main characteristics of the previously described proline-specific transport mechanism (permease) of Escherichia coli were confirmed in strain C4. The same permease was responsible for entry of a number of proline analogues, including 3,4-dehydroproline, 4-methyleneproline, cis- and trans-4-chloroprolines, thiazolidine-4-carboxylic acid (thioproline) and the lower homologue, azetidine-2-carboxylic acid. These analogues also entered the cells by an exchange reaction between extracellular analogue and previously accumulated intracellular proline. Growth of the parent (c4) strain was inhibited by 3,4-dehydroproline and azetidine-2-carboxylic acid, both of which were incorporated into cellular protein. Several classes of mutants, selected for resistance to either dehydroproline or azetidine, failed to incorporate one or both analogues into protein. Some of these mutants owed their resistance to failure to produce a functional proline permease. At least one strain, resistant to azetidine but not to dehydroproline, possessed an altered permease with little affinity for azetidine-2-carboxylic acid but still capable of transporting proline and 3,4-dehydroproline; the permease of this strain could no longer promote exchange between intracellular proline and extracellular proline or proline analogues.
\end{abstract}

\section{INTRODUCTION}

Exposure of bacterial cells to a wide variety of structural analogues of 'protein' amino acids results in inhibition of growth, frequently accompanied by incorporation of the analogue into the proteins of the organism (Cohen \& Munier, 1959; Munier \& Cohen, 1959; Richmond, I962; Fowden, Lewis \& Tristram, 1967). Recently, two analogues of proline have been investigated, namely, azetidine-2-carboxylic acid (a 'non-protein' amino acid occurring naturally in certain higher plants) and 3,4dehydroproline. These compounds are strongly growth-inhibitory to Escherichia coli and some higher plants, inhibition being specifically annulled by proline. Both analogues are incorporated into the proteins of these organisms, stoichiometrically replacing proline residues (Smith, Ravel, Skinner \& Shive, I962; Fowden \& Richmond, 1963; Fowden, Neale \& Tristram, 1963; Peterson \& Fowden, 1965). Incorporation of dehydroproline into the alkaline phosphatase of $E$. coli has been shown to result in a marked increase in thermolability of the enzyme (Neale \& Tristram, 1964). Thiazolidine-4-carboxylic acid (thioproline) also inhibits growth and is incorporated into the proteins of $E$. coli (Beerstecher, I950; Unger \& DeMoss, 1966). The biological activi- 
ties of other proline analogues have recently been reviewed (Mauger \& Witkop, 1966; Fowden et al. 1967).

Numerous examples of the development of resistance to growth-inhibitory amino acid analogues have been described (Moyed, 1964; Richmond, 1965; Fowden et al. 1967). The mechanisms whereby resistance is acquired vary; one type of resistance involves mutation leading to failure of the analogue to penetrate into the cell, thereby excluding the analogue from the site (or sites) at which toxicity is exerted. Several investigators have described the isolation of analogue-resistant bacterial strains which failed to accumulate either the analogue or the corresponding natural amino acid (Schwartz, Maas \& Simon, 1959; Ferroluzzi-Ames, 1964; Shifrin, Ames \& FerroluzziAmes, 1966; Lester, 1966). These observations not only provide an explanation of the mechanism of resistance, but also demonstrate that the analogues enter the cell by the specific transport mechanisms normally responsible for entry of the corresponding natural amino acids. The latter conclusion was also reached in a study of the uptake of phenylalanine and its analogue, $p$-fluorophenylalanine by Escherichia coli (Kempner \& Cowie, 1960).

A specific energy-dependent transport mechanism (permease) permitting the accumulation of proline by Escherichia coli has been described (Britten \& McClure, 1962; Britten, 1965; Kessel \& Lubin, 1962). Strains deficient in proline permease activity have been obtained (Lubin, Kessel, Budreau \& Gross, 1960; Kessel \& Lubin, 1962). Evidence will be presented that 3,4-dehydroproline, azetidine-2-carboxylic acid and some other proline analogues are accumulated in the cell by the proline permease and that, compared with the parent strain, some of the mutants resistant to the two named analogues have an impaired ability to concentrate proline. A preliminary account of some of these experiments has already been presented (Neale \& Tristram, 1965).

\section{METHODS}

Chemicals. L-Proline, $N$-acetyl-DL-proline and glycyl-L-proline were obtained from the Sigma Chemical Company; D-proline, L- and D-azetidine-2-carboxylic acid from Calbiochem; L-thiazolidine-4-carboxylic acid, DL-pipecolic acid, 4,5-dehydro-DLpipecolic acid, 4-methylene-DL-proline, $c i s$ - and trans-4-chloro-L-proline were the gift of Professor L. Fowden, F.R.S.; 3,4-dehydro-DL-proline was a gift from Dr B. Witkop and Professor A. V. Robertson. Labelled amino acids were purchased from the Radiochemical Centre, Amersham, Buckinghamshire, England. All amino acids and analogues were checked for purity by chromatography. Where possible, all other chemicals were 'Analar' grade, obtained from British Drug Houses Ltd.

Media. The basal glucose mineral salts medium (designated $232 \mathrm{G}$ ) described by Tristram (I960) was used throughout the investigation. For selection of analogueresistant mutants, the medium was supplemented with $25 \mu \mathrm{g}$. 3,4-dehydro-DL-proline/ ml. (232 G/DHP), or $25 \mu \mathrm{g}$. L-azetidine-2-carboxylic acid/ml. (232 G/Az). Solid media were prepared by addition of $2 \%(\mathrm{w} / \mathrm{v})$ Bacto agar. The effect of analogues on growth was measured in shaken cultures at $37^{\circ}$ as described by Neale \& Tristram (1963).

Organisms. Escherichia coli $\mathrm{C} 4$ (a strain derived from $\mathrm{K}-\mathrm{IO}$ ), isolated and described by Echols, Garen, Garen \& Torriani (196I), was used as the source of analogueresistant strains described below. Strains resistant to 3,4-dehydroproline were isolated by plating between $10^{8}$ and $10^{9}$ bacteria of strain $\mathrm{C} 4$ (without exposure to mutagens) on 
$232 \mathrm{G} / \mathrm{DHP}$ agar. Similar attempts to isolate azetidine-resistant strains by plating on $232 \mathrm{G} / \mathrm{Az}$ resulted, after a lag, in a sparse 'lawn' of growth which covered the plates. Accordingly, strains resistant to this analogue were obtained by repeated passage of E. coli $\mathrm{C} 4$ through $232 \mathrm{G} / \mathrm{Az}$ liquid medium, followed by plating on $232 \mathrm{G} / \mathrm{Az}$ agar to obtain individual colonies. Resistant colonies were picked from $232 \mathrm{G} / \mathrm{DHP}$ and $232 \mathrm{G} / \mathrm{Az}$ plates, purified by streaking on the same media and maintained on slopes of $232 \mathrm{G} / \mathrm{DHP}$ or $232 \mathrm{G} / \mathrm{Az}$ agar in which the glucose concentration was reduced to $0.1 \%(w / v)$ to prevent development of highly acid conditions. Mutants were allocated numbers prefixed by 'DHP' or 'AZ', denoting strains selected for resistance to 3,4dehydroproline or azetidine-2-carboxylic acid respectively.

Excretion of proline by analogue-resistant mutants was detected on double-layer plates consisting of a lower layer of $232 \mathrm{G}$ agar covered by a thin layer of the same medium in which was suspended about $\mathrm{I}^{\mathbf{1 0}}$ organisms of Escherichia coli strain H 208 (a proline-dependent derivative of KI2, kindly provided by Dr K. Fisher). Mutants were streaked on such plates and proline excretion detected by cross-feeding of the auxotrophic strain suspended in the agar.

Accumulation of amino acids; measurement of exchange between intra- and extracellular amino acids. The procedure for measurement of the uptake of amino acids was essentially that described by Britten \& McClure (1962). Unless otherwise stated, uptake was followed in continuously aerated suspensions containing I $25 \mu \mathrm{g}$. dry wt. organism/ $\mathrm{ml}$. and maintained at $10^{\circ}$. In those experiments involving uptake in the presence of chloramphenicol, exponential cultures growing in $232 \mathrm{G}$ at $37^{\circ}$ were cooled to $10^{\circ}$ and, when necessary, diluted with $232 \mathrm{G}$ medium, followed by addition of chloramphenicol (in $232 \mathrm{G}$ medium) to give a final concentration of $150 \mu \mathrm{g} . / \mathrm{ml}$. The suspensions were distributed in suitable amounts in Pyrex tubes, aerated with a stream of water-saturated air and used within 15 min. of addition of chloramphenicol. For experiments not involving addition of chloramphenicol, cultures growing exponentially at $37^{\circ}$ were transferred to $10^{\circ}$ and aeration continued for $2 \mathrm{hr}$ before dilution and distribution as already described. Additions of amino acids and/or analogues were made in volumes not exceeding $\mathrm{I} \%(\mathrm{v} / \mathrm{v})$ of the total volume of suspensions. Total intracellular radioactivity was measured by filtration of I ml. samples through Millipore filters (type HA; $23 \mathrm{~mm}$. diameter) held in stainless steel holders (Tracerlab) and covered, immediately prior to receiving the sample, with $2 \mathrm{ml}$. ice-cold $232 \mathrm{G}$ medium. After filtration, which occupied about $5 \mathrm{sec}$., filters were transferred to aluminium or stainless steel planchets, held in position by a slip-on retaining ring (Tracerlab), dried over calcium chloride and counted by use of a thin end-window G-M tube (Isotope Developments Ltd., England). In all instances at least Iooo counts over background were obtained and, where necessary, counts were converted into $\mu$ moles amino acid by calculation from specific radioactivities and the known efficiency of the counting equipment. For kinetic studies, the amount of radioactivity taken up by suspensions could be determined at $20 \mathrm{sec}$. intervals and the initial rates of uptake were calculated by the method of Algranati (I963).

In earlier experiments involving exchange between accumulated radioactive proline and extracellular unlabelled proline or analogue, the bacteria were 'loaded' by exposure to $1 \cdot 22 \times \mathrm{IO}^{-7} \mathrm{M}$ - or $2 \times \mathrm{IO}^{-6} \mathrm{M}-\mathrm{L}-\left[\mathrm{U}-{ }^{14} \mathrm{C}\right]$ proline for $20 \mathrm{~min}$. or $40 \mathrm{~min}$., respectively, at $10^{\circ}$ in aerated $232 \mathrm{G}$ medium containing chloramphenicol (I $50 \mu \mathrm{g}$.) $\mathrm{ml}$.). Later exchange experiments involved exposing bacteria, suspended in $232 \mathrm{G}$ 
medium containing chloramphenicol, to $\mathrm{I} \cdot 22 \times \mathrm{IO}^{-7} \mathrm{M}-\mathrm{L}-\left[\mathrm{U}-{ }^{14} \mathrm{C}\right]$ proline for $\mathrm{Io} \mathrm{min}$. at $25^{\circ}$. The suspensions were then cooled to $0^{\circ}$ with continuous aeration for $15 \mathrm{~min}$., followed by centrifugation at $0^{\circ}$ (10,000 $\mathrm{g}$; Io min.) or rapid filtration through HA Millipore membrane filters ( $47 \mathrm{~mm}$. diameter) and resuspension of the cells in fresh $232 \mathrm{G}$ medium, previously cooled to $0^{\circ}$ containing chloramphenicol (I $50 \mu \mathrm{g} . / \mathrm{ml}$.). Aeration at $0^{\circ}$ was continued for at least a further $30 \mathrm{~min}$. before exchange commenced. In both procedures the exchange reaction was initiated by rapid addition of a suitable sample of preloaded bacteria to Pyrex tubes already containing a solution of the compound to be tested for exchange activity. Samples were filtered and intracellular radioactivity measured as described above.

Incorporation of amino acids and analogues into protein; extraction of free amino acid pool. Incorporation of analogues into protein was determined after acid hydrolysis of the 'principal protein fraction' (Roberts et al. 1955) of dehydroproline-containing protein or, for azetidine-containing protein, by alkaline hydrolysis, as described previously (Neale \& Tristram, 1963). Proline in hydrolysates was assayed after electrophoresis on Whatman $3 \mathrm{MM}$ paper (6000 V.; $30 \mathrm{~mA}$.; formic + acetic acid buffer, $\mathrm{pH} \mathrm{2,} \mathrm{containing} 6 \mathrm{I} \cdot 2 \mathrm{ml}$. formic acid and $97.2 \mathrm{ml}$. acetic acid per litre of solution), followed by spraying with isatin and comparison of spot intensities with those of standard proline solutions, using a 'Chromoscan' (Joyce-Loebl and Co. Ltd., Newcastle-on-Tyne, England) fitted with filter 595 (A. Hussain, personal communication). 3,4-Dehydroproline was assayed on the same electrophoretogram by over-spraying with Ehrlich's reagent (Fowden, Neale \& Tristram, 1963) and scanning as described above. Azetidine-2-carboxylic acid in hydrolysates was determined after two-dimensional chromatography, as described by Fowden \& Richmond (1963).

Before extraction of the free amino acid 'pool', bacterial suspensions were centrifuged $(20,000 \mathrm{~g} ; \mathrm{I} 5 \mathrm{~min}$.) at the temperature at which amino acid accumulation occurred (to avoid changes in 'pool' size due to temperature shock). The pellet of bacteria was resuspended in $70 \%(\mathrm{v} / \mathrm{v})$ ethanol in water to extract the amino acid 'pool' and, after overnight storage at $4^{\circ}$, cell debris was removed by centrifugation and the constituents of the ethanol-soluble fraction separated and detected by conventional chromatography or by electrophoresis as already described. Radioautography was carried out on 'Kodirex' X-ray film.

Incorporation of radioactivity into trichloroacetic acid-insoluble material was determined as described by Neale \& Tristram (1963).

\section{RESULTS}

\section{Growth in the presence of analogues}

In common with many amino acid analogues (see reviews by Richmond, I962; Fowden et al. 1967), addition of 3,4-dehydro-DL-proline (25 $\mu \mathrm{g} . / \mathrm{ml}$.) or L-azetidine-2carboxylic acid $(20 \mu \mathrm{g} . / \mathrm{ml}$.) to cultures of Escherichia coli strain $\mathrm{C} 4$ growing exponentially in $232 \mathrm{G}$ medium resulted in 'linear' growth, i.e. whereas the extinction of control cultures increased exponentially, in the presence of the analogue increase in extinction was arithmetic. In cultures containing azetidine, onset of linear growth was virtually immediate. However, in cultures receiving dehydroproline there was little effect on growth for the first $40 \mathrm{~min}$. of exposure, after which linear increase in optical density was established (Fig. I $a, b$; see also Fowden et al. 1963). 
Addition of analogues to exponentially growing cultures of suitable bacterial concentration was advocated by Cohen \& Munier (1959) and allows a sufficient increase in dry weight of organism to facilitate isolation and study of incorporation of analogues into cell protein. When either 3,4-dehydro-DL-proline $(25 \mu \mathrm{g}$. $/ \mathrm{ml}$.) or L-azetidine2-carboxylic acid $(20 \mu \mathrm{g} . / \mathrm{ml}$.) were added to $232 \mathrm{G}$ medium at the same time as inoculation with a small inoculum (about $5 \times 10^{5}$ bacteria $/ \mathrm{ml}$.), then detectable growth was completely inhibited for at least $\mathrm{I} 2 \mathrm{hr}$. Addition of much higher $(400 \mu \mathrm{g} . / \mathrm{ml}$.) concentrations of L-thiazolidine-4-carboxylic acid yielded a curve similar to that

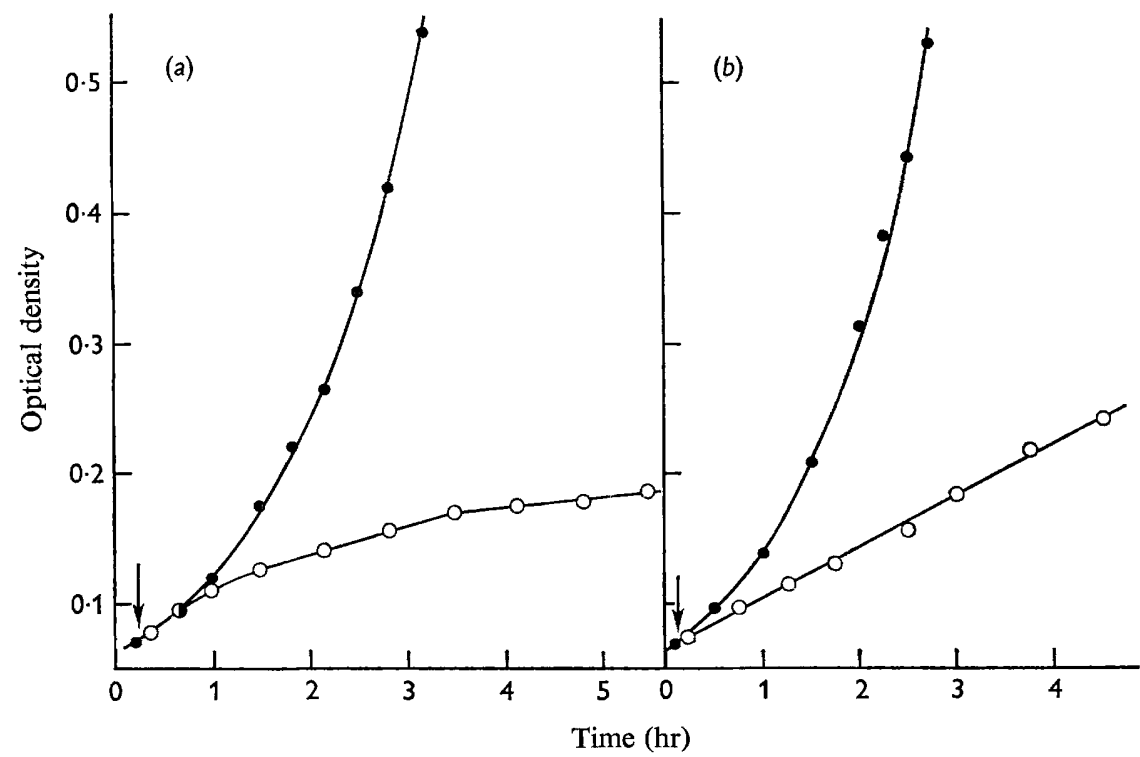

Fig. I. The effect of addition of (a) L-azetidine-2-carboxylic acid (20 $\mu \mathrm{g} . / \mathrm{ml}$.) and (b) 3,4dehydro-DL-proline $(25 \mu \mathrm{g} . / \mathrm{ml}$.) to exponential cultures of Escherichia coli $\mathrm{C} 4$ growing in $232 \mathrm{G}$ medium at $37^{\circ}$. Analogues were added at points indicated by arrows.

Control (no analogue); $\bigcirc-O$, plus analogue.

obtained on addition of 3,4-dehydroproline, thus confirming the observations of Unger \& DeMoss (1966). Cis- or trans-4-chloro-L-prolines did not inhibit growth of Escherichia coli $\mathrm{C} 4$ at concentrations up to $200 \mu \mathrm{g}$. analogue $/ \mathrm{ml}$., nor was growth inhibited by DL-pipecolic acid or 4,5-dehydro-DL-pipecolic acid, in agreement with earlier observations (Fowden \& Richmond, 1963).

In studying growth of mutants resistant to 3,4-dehydroproline or azetidine, $232 \mathrm{G}$, $232 \mathrm{G} / \mathrm{DHP}$ and $232 \mathrm{G} / \mathrm{Az}$ media were inoculated with bacteria growing exponentially in $232 \mathrm{G}$ medium to give an initial bacterial concentration equiv. to about $10 \mu \mathrm{g}$. dry wt bacteria/ml. Dehydroproline-resistant strains grew in the presence of 3,4-dehydroproline or azetidine at rates comparable with that displayed by the parent (C4) strain in the absence of analogue. All dehydroproline-resistant strains tested displayed crossresistance to both analogues. However, although fewer resistant strains were isolated when using azetidine as selective agent, all those tested (fourteen in all) were completely resistant to azetidine (judged by their capacity to grow in $232 \mathrm{G} / \mathrm{Az}$ medium at rates comparable with that of the parent strain in $232 \mathrm{G}$ medium), but were still 
sensitive to growth inhibition by dehydroproline when inoculated into $232 \mathrm{G} / \mathrm{DHP}$ medium.

\section{Incorporation of analogues into proteins of parent and mutant strains}

The 'principal protein fraction' (Roberts et al. 1955) isolated from strains grown in $232 \mathrm{G}, 232 \mathrm{G} / \mathrm{DHP}$ and $232 \mathrm{G} / \mathrm{Az}$ was examined for the presence of incorporated analogues (see Methods). As previously reported (Fowden \& Richmond, 1963; Fowden et al. 1963), both 3,4-dehydroproline and azetidine were incorporated into proteins of wild-type Escherichia coli, with a corresponding decrease in the proline content (Table I). Although not all the analogue-resistant strains isolated were tested,

Table I. Incorporation of 3,4-dehydroproline and azetidine-2-carboxylic acid into the 'principal protein fraction' of Escherichia coli $\mathrm{C} 4$ and analogue-resistant derivatives

Organisms were grown at $37^{\circ}$ in $232 \mathrm{G}, 232 \mathrm{G} / \mathrm{DHP}$ and $232 \mathrm{G} / \mathrm{Az}$ media. The "principal protein fraction' was isolated, hydrolysed and the content of proline and, where appropriate, 3,4-dehydroproline and azetidine-2-carboxylic acid determined (see Methods). Cultures grown in the presence of analogues were harvested after a 2.5- to 3-fold increase in extinction. Figures reported are not corrected for the proline content of analogue-free protein present in cells before addition of analogues (see Fowden \& Richmond, 1963; Fowden et al. 1963). The proline content of all strains harvested during exponential growth in $232 \mathrm{G}$ medium was about $24 \mu \mathrm{g}$. proline/mg. 'principal protein fraction'.

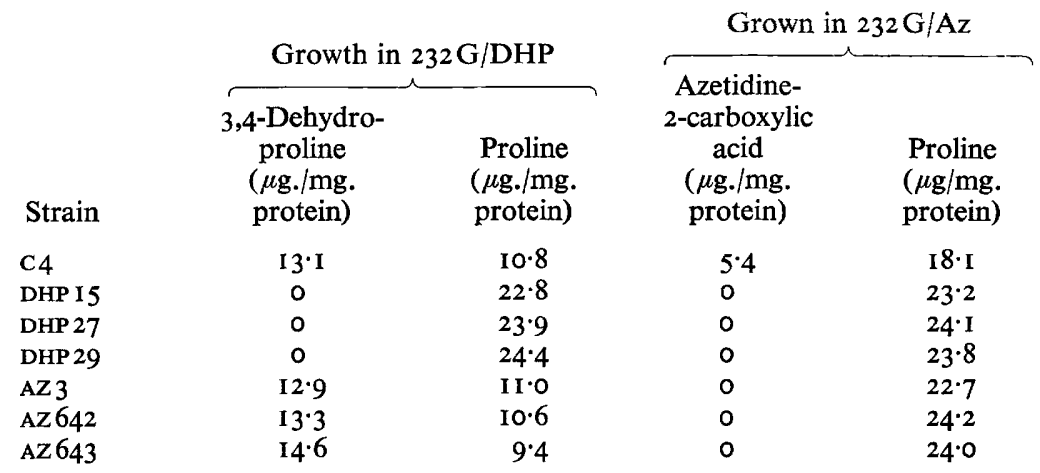

the results presented in Table I show that dehydroproline-resistant strains (also crossresistant to azetidine) did not incorporate either dehydroproline or azetidine into protein, whereas strains which had been selected for resistance to azetidine did not incorporate this analogue but still incorporated dehydroproline into cell proteins. Moreover, the degree of incorporation of dehydroproline by these azetidine-resistant strains was comparable with that observed in strain $\mathrm{C}_{4}$ (Table $\mathrm{I}$ ).

\section{Excretion of proline by analogue-resistant mutants}

Excretion of proline was detected by ability to cross-feed proline auxotrophs (see Methods). Whereas many strains selected for resistance to dehydroproline excreted proline, most azetidine-resistant strains studied were unable to cross-feed prolinedependent organisms. The significance of proline excretion will be discussed below (see Discussion). 
Proline uptake by the parent strain

Addition of $1 \mathrm{1}^{-6} \mathrm{M}-\mathrm{L}-\left[\mathrm{U}-{ }^{14} \mathrm{C}\right]$ proline to a suspension of Escherichia coli $\mathrm{C} 4$ maintained at $10^{\circ}$ in the absence of chloramphenicol resulted in rapid accumulation of radioactivity in the cells (Fig. 2). Incorporation into TCA-insoluble material was linear for about $40 \mathrm{~min}$., the rate of incorporation subsequently decreasing with approaching exhaustion of added proline. The proline 'pool' (obtained as the difference between

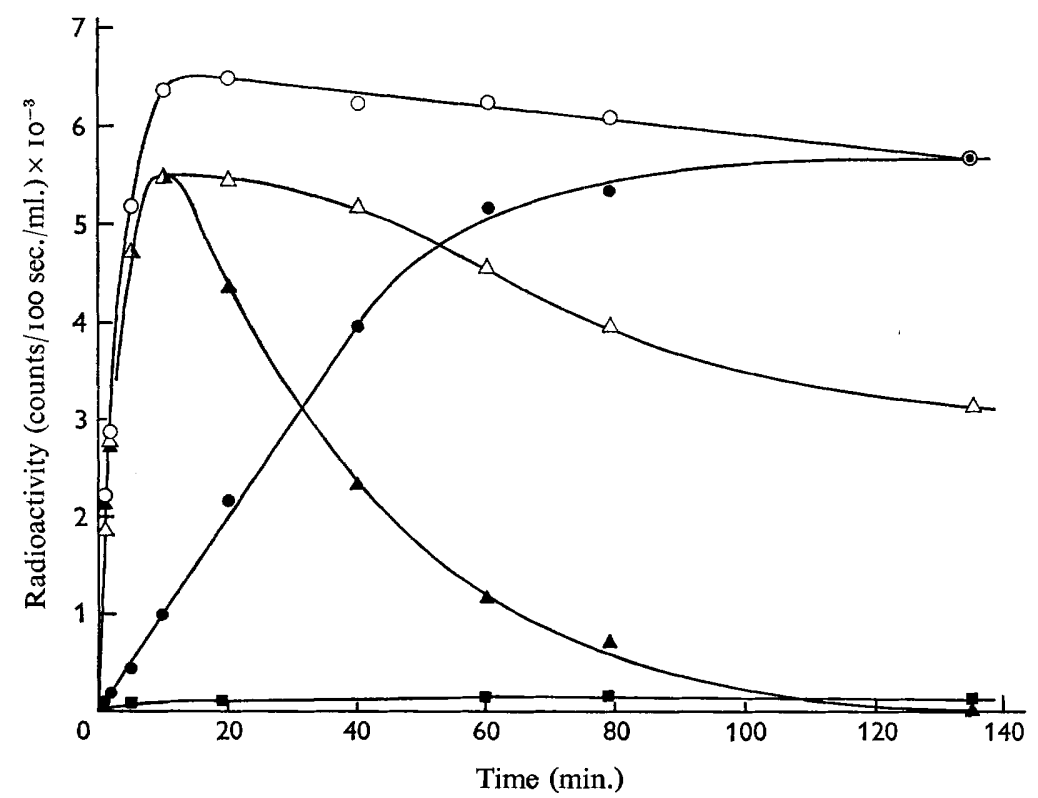

Fig. 2. Total uptake and incorporation of radioactivity into trichloroacetic acid-insoluble material by Escherichia coli $\mathrm{C} 4$ in the presence of ${ }^{{ }^{1} 0^{-6}} \mathrm{M}-\mathrm{L}-\left[\mathrm{U}-{ }^{14} \mathrm{C}\right]$ proline $(3 \mathrm{I} \cdot 25 \mu \mathrm{c} . / \mu \mathrm{mole})$. Bacteria (equiv. I25 $\mu \mathrm{g}$. dry wt $/ \mathrm{ml}$.) were suspended in $232 \mathrm{G}$ medium, with or without addition of chloramphenicol $\left(150 \mu \mathrm{g} . / \mathrm{ml}\right.$.) and aerated at $10^{\circ}$. In the absence of chloramphenicol: $\mathrm{O}-\mathrm{O}$, total uptake; -0 , incorporation into the trichloroacetic acidinsoluble fraction; $\mathbf{A}-\mathbf{\Lambda}$, calculated proline 'pool' (total uptake minus trichloroacetic acidinsoluble fraction). In the presence of chloramphenicol: $\Delta-\Delta$, total uptake (= 'pool'); a-m, incorporation into the trichloroacetic acid-insoluble fraction.

total uptake and TCA-insoluble incorporated material) rose to a maximum after Io min. and then decreased as the limited amount of proline supplied passed into protein. In the presence of chloramphenicol, incorporation into protein was suppressed, and the total uptake may be taken as representing incorporation into the 'pool'. Although under these conditions some radioactivity was lost from the bacteria, the initial rate of accumulation in the 'pool' was identical in the presence or absence of chloramphenicol (Fig. 2). This overall picture of proline uptake in strain $\mathrm{C} 4$ is similar to that described for E. coli B by Britten \& McClure (1962).

The addition of relatively high concentrations of labelled proline to $E$. coli strain $\mathrm{C} 4$ at $10^{\circ}$ in the presence of chloramphenicol resulted in rapid uptake of radioactivity which reached a maximum and subsequently decreased due to leakage of accumulated proline. This effect was less pronounced at lower initial proline concentrations. For 
example, in the presence of $2 \times 10^{-6} \mathrm{M}$-L-proline about $50 \%$ of the accumulated proline was lost in $150 \mathrm{~min}$. In the same time-period leakage accounted for $38 \%, 32 \%, 25 \%$ and $17 \%$ of the maximum 'pool' size after addition of $10^{-6} \mathrm{M}, 2.6 \times 10^{-7} \mathrm{M}, 10^{7} \mathrm{M}$ and $0.33 \times 10^{-7} \mathrm{M}-\mathrm{L}-\left[\mathrm{U}-{ }^{14} \mathrm{C}\right]$ proline, respectively. This 'overshoot' phenomenon has been noticed by W. Maas (personal communication) during investigation of the arginine permease of $E$. coli, and has been studied and discussed in detail with respect to sulphate transport in Salmonella typhimurium (Dreyfuss \& Pardee, 1966).

Following uptake of $\mathrm{L}-\left[\mathrm{U}-{ }^{14} \mathrm{C}\right]$ proline in the presence of chloramphenicol, extraction of the 'pool' followed by chromatography and radioautography (see Methods) revealed that virtually all the accumulated radioactivity could be accounted for as proline. Similarly, after uptake of the labelled amino acid in the absence of chloramphenicol followed by isolation, and hydrolysis and electrophoresis of the 'principal protein fraction', only the proline spot was labelled.

\section{Inhibition of proline accumulation by analogues}

Since radioactively labelled analogues were not available, their uptake could not be measured directly. A measure of the affinity of the proline permease for proline analogues was obtained by investigating inhibition of $\mathrm{L}-\left[\mathrm{U}-{ }^{14} \mathrm{C}\right]$ proline uptake by the

Table 2. Inhibition of uptake of $L-\left[U_{-1}{ }^{14} C\right]$ proline by proline analogues in Escherichia coli strain $\mathrm{C4}$

Bacterial suspensions (equiv. $125 \mu \mathrm{g}$. dry wt bacteria/ml.) in $232 \mathrm{G}$ medium containing chloramphenicol ( $150 \mu \mathrm{g} . / \mathrm{ml}$.) at $10^{\circ}$ were simultaneously exposed to $1 \cdot 22 \times \mathrm{IO}^{-7} \mathrm{M}-\mathrm{L}$ [U-14 C]proline and $\mathrm{I} \cdot \mathrm{I} \times 10^{-4} \mathrm{M}$-analogue (or unlabelled proline), as indicated below. Analogue concentrations were calculated on the basis of the content of L-isomer. Results are expressed as percentage inhibition of the initial rate of uptake in the presence of $1 \cdot 22 \times 10^{-7}$ $\mathrm{M}-\mathrm{L}-\left[\mathrm{U}-{ }^{14} \mathrm{C}\right]$ proline only.

\begin{tabular}{lc}
\multicolumn{1}{c}{ Addition } & $\begin{array}{c}\text { Inhibition } \\
(\%)\end{array}$ \\
L-Proline (unlabelled) & $95 \cdot 7$ \\
3 4-Dehydro-DL-proline & $94 \cdot 8$ \\
L-Thiazolidine-4-carboxylic acid & $86 \cdot 7$ \\
L-Azetidine-2-carboxylic acid & $77 \cdot 5$ \\
4-Methylene-DL-proline & $75 \cdot 9$ \\
cis-4-Chloro-L-proline & $76 \cdot 1$ \\
trans-4-Chloro-L-proline & $56 \cdot 9$ \\
Glycyl-L-proline & $13 \cdot 9$ \\
D-Proline & 0 \\
D-Azetidine-2-carboxylic acid & 0 \\
N-Acetyl-DL-proline & 0 \\
DL-Pipecolic acid & 0 \\
4,5-Dehydro-DL-pipecolic acid & 0
\end{tabular}

analogues. Table 2 (line I) reveals that the presence of excess unlabelled proline inhibited accumulation of radioactive proline. Many analogues, including 3,4dehydro-DL-proline, L-thiazolidine-4-carboxylic acid and a number of 4-substituted prolines had a similar effect. The lower homologue of proline, L-azetidine-2-carboxylic acid also inhibited the uptake of labelled proline, though to a lesser degree; on the other hand, the higher homologue of proline, DL-pipecolic acid, together with 4,5dehydro-DL-pipecolic acid and $N$-acetyl-DL-proline were without effect (Table 2).

When studied as a function of initial proline concentration, the initial rates of uptake in the presence of chloramphenicol obeyed Michaelis-Menten kinetics (Fig. 3), with 
a $K_{m}$ of $6.4 \times 10^{-7} \mathrm{M}$. Inhibition of proline uptake into the amino acid pool by 3,4 dehydroproline and azetidine was studied in detail. Inhibition by both analogues was competitive (Fig. 3). Calculation of $K_{i}$ (see Dixon \& Webb, I964) yielded a value of $2.6 \times 10^{-6} \mathrm{M}$ and $2.4 \times 10^{-5} \mathrm{M}$ for 3,4-dehydroproline and azetidine, respectively. It should be noted that, since only racemic (DL) 3,4-dehydroproline was available, the calculation of $K_{i}$ for this analogue was based on the assumption that only the Lisomer was active in inhibiting uptake of proline. Thus, in the parent strain Escherichia coli $\mathrm{C} 4$, the affinity of the proline transport system for 3,4-dehydroproline was comparable with that for proline itself, but affinity of the system for azetidine was considerably lower (see also Table 2).

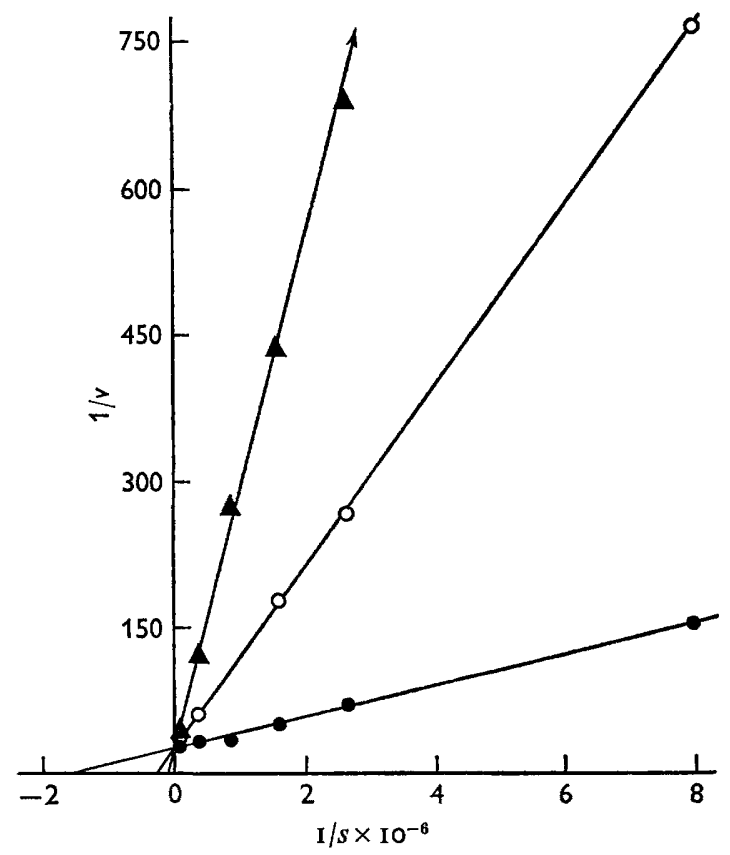

Fig. 3. Lineweaver-Burk plot of the initial rate of uptake of radioactivity as a function of $\mathrm{L}-\left[\mathrm{U}-{ }^{14} \mathrm{C}\right]$ proline concentration in the presence and absence of $5 \times 10^{-5} \mathrm{M}-3,4$-dehydro-DLproline or $1^{-4} \mathrm{M}-\mathrm{L}$-azetidine-2-carboxylic acid. Escherichia coli $\mathrm{C} 4$, suspended in $232 \mathrm{G}$ medium containing chloramphenicol ( $150 \mu \mathrm{g} . / \mathrm{ml}$.), were aerated at $10^{\circ}$. Various concentrations of substrate were obtained by addition of suitable amounts of carrier L-proline to $\mathrm{L}-\left[\mathrm{U}-{ }^{14} \mathrm{C}\right]$ proline $(\mathrm{I} 30 \mu \mathrm{c} . / \mu \mathrm{mole})$. $-\mathrm{O}$, L-proline only; $\mathrm{O}-\mathrm{O}$, L-proline $+\mathrm{L}-$ azetidine2-carboxylic acid; $\boldsymbol{\Delta}-\boldsymbol{\Delta}$, L-proline +3,4-dehydro-DL-proline.

\section{Accumulation of proline by analogue-resistant mutants}

A wide range of strains selected for resistance to either 3,4-dehydroproline or azetidine were tested for their ability to accumulate labelled proline. Some resistant strains appeared to take up labelled proline at rates comparable to that displayed by the parent strain Escherichia coli $\mathrm{C} 4$. However, in many other mutants the capacity to accumulate proline was impaired. A representative group of results are shown in Fig. 4 . The activity of the impaired permease varied from virtually complete absence to values with which the initial rate of proline uptake was about $25 \%$ of that measured in the parent strain $\mathrm{C} 4$. In many of the strains selected on 3,4-dehydroproline, the 
kinetics of proline uptake were abnormal (see strain DHP 2I, Fig. 4) in that radioactivity entered the bacteria at a high rate, but was quickly lost. These strains also excreted proline in considerable amounts. The significance of this behaviour will be considered in a later publication.

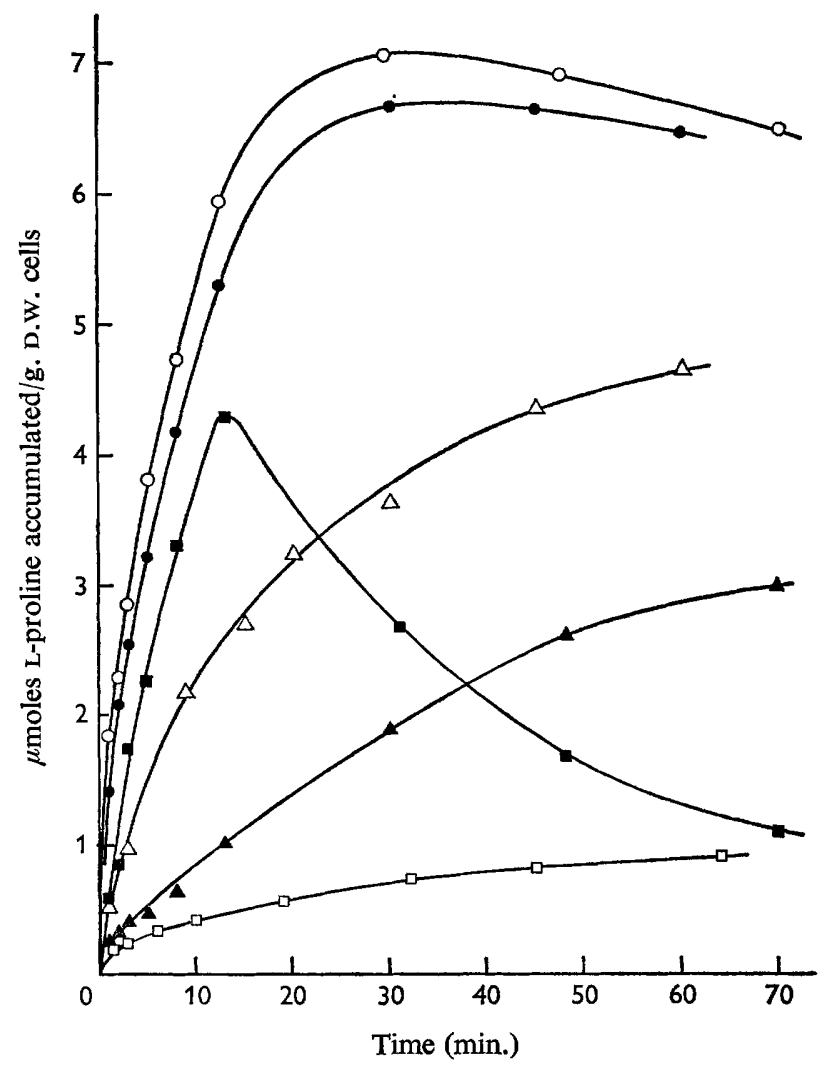

Fig. 4. Uptake of radioactivity by Escherichia coli wild-type $\mathrm{C} 4$ and analogue-resistant strains in the presence of $2 \times 10^{-6} \mathrm{M}-\mathrm{L}-\left[\mathrm{U}-{ }^{14} \mathrm{C}\right]$ proline $(3 \mathrm{I} \cdot 25 \mu \mathrm{c} / \mu \mathrm{mole})$. Bacteria (equiv. $125 \mu \mathrm{g}$. dry $\mathrm{wt} / \mathrm{ml}$.) were suspended in $232 \mathrm{G}$ medium containing chloramphenicol (150 $\mu \mathrm{g} . / \mathrm{ml}$.). Azetidine-resistant strains: $\Delta-\Delta, \mathrm{Az}_{3} ; \triangle-\triangle$, Az 642; - - , Az 643. 3,4-Dehydroprolineresistant strains: $\square-\square$, DHP 2 I ; $\square-\square$, DHP 27. O-O, strain C4.

The presence of $10^{-3} \mathrm{M}-2,4$ dinitrophenol almost completely suppressed the uptake of $2 \times 10^{-6} \mathrm{M}-\mathrm{L}-\left[\mathrm{U}-{ }^{14} \mathrm{C}\right]$ proline by the parent strain and by those mutants having somewhat impaired permease activity. However, the inhibitor was without significant effect on the very low intracellular levels of those strains which were virtually devoid of permease activity (see also Britten \& McClure, 1962; Kessel \& Lubin, 1962).

The uptake of $\mathrm{I} \cdot 65 \times \mathrm{IO}^{-6} \mathrm{M}-\mathrm{L}-\left[\mathrm{U}-{ }^{14} \mathrm{C}\right]$ arginine ( $2.5 \mathrm{~m} \mu \mathrm{c} / \mathrm{ml}$. suspension) by the parent and all mutant strains tested was identical, suggesting that the impaired permease activity of the mutants was specific for the proline permease.

The mutants selected for azetidine-resistance were of particular interest since the majority of these strains were not cross-resistant to 3,4-dehydroproline, and the latter compound was still incorporated into protein (see Table I). The affinity of the per- 
mease of one of these strains (Az642) for proline $\left(K_{m}=9.0 \times 10^{-7} \mathrm{M}\right)$ and 3,4-dehydroproline $\left(K_{i}=3.6 \times 10^{-6} \mathrm{M}\right)$ differed only slightly from that found for the parent strain. However, in strain Az 642, uptake of proline was much less sensitive to inhibition by L-azetidine-2-carboxylic acid compared with the parent (C4) strain (Fig. 5). The $K_{i}$ for azetidine determined for $\mathrm{AZ} 642$ was $3.0 \times \mathrm{IO}^{-4} \mathrm{M}$, an approximately tenfold increase over the corresponding value for strain $\mathrm{C} 4$. As in the parent strain, both analogues competitively inhibited uptake of proline in strain AZ 642 .

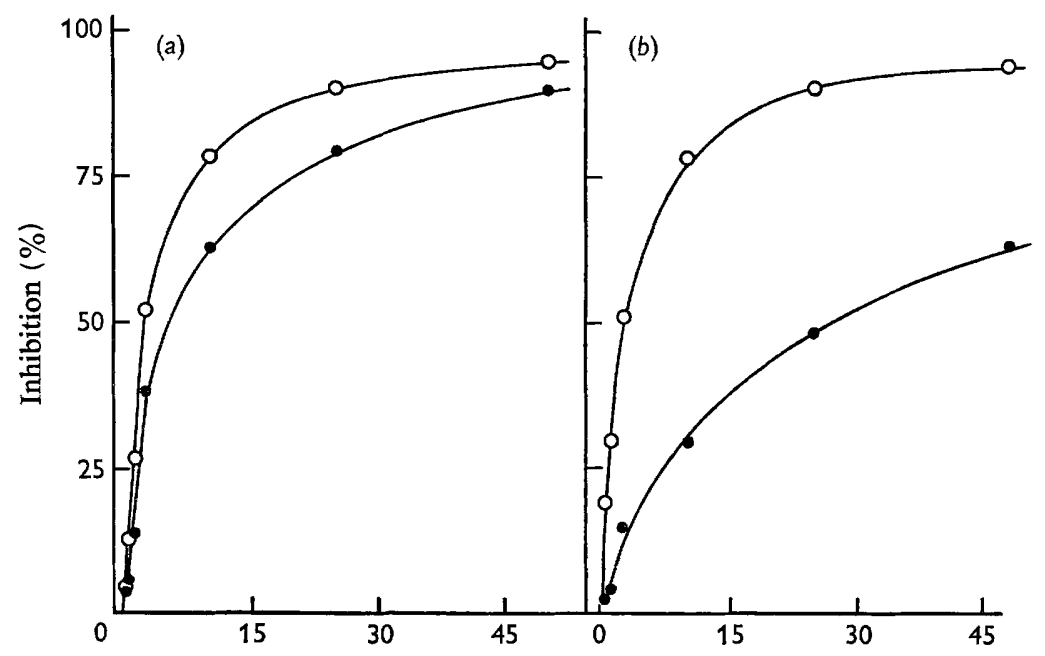

3,4-Dehydroproline ( $\mathrm{M} \times 1 \mathrm{IO}^{-6} \mathrm{~L}$ isomer) L-Azetidine-2-carboxylic acid $\left(\mathrm{M} \times \mathrm{IO}^{-5}\right)$

Fig. 5. Inhibition of uptake of labelled proline by varying concentrations of (a) 3,4-dehydroproline and (b) azetidine-2-carboxylic acid by Escherichia coli $\mathrm{C} 4$ and the azetidineresistant strain AZ642. Bacteria (equiv. I25 $\mu \mathrm{g}$. dry wt $/ \mathrm{ml}$.) were aerated at $10^{\circ}$ in $232 \mathrm{G}$ medium containing chloramphenicol ( $150 \mu \mathrm{g} . / \mathrm{ml}$.), to which was added $\mathrm{I} \cdot 22 \times \mathrm{IO}^{-7} \mathrm{M}-\mathrm{L}-$ [U-14 Clproline (I $30 \mu \mathrm{c} / \mu \mathrm{mole}$ ) and, where necessary, either 3,4-dehydro-DL-proline or L-azetidine-2-carboxylic acid at concentrations indicated. Uptake of radioactivity was measured at $20 \mathrm{sec}$. intervals over the first $80 \mathrm{sec}$. and results are expressed as $\%$ inhibition of the initial rate of proline uptake in the absence of inhibitor. $\mathrm{O}-\mathrm{O}$, Strain $\mathrm{C} 4$; $\bullet-\bullet$, azetidine-resistant strain AZ642.

\section{Exchange between intracellular proline and extracellular proline or analogues}

Several investigators have shown that a variety of metabolites, once accumulated in the intracellular 'pool', can exchange with extracellular metabolite (Cohen \& Kepes, 1962; Kessel \& Lubin, 1962; Britten \& McClure, 1962; Britten, I965). Experiments with Escherichia coli strain $\mathrm{C} 4$ confirmed the results obtained with $E$. coli $\mathrm{B}$ by Britten $\&$ McClure (1962). Proline accumulation did not occur at $0^{\circ}$, though proline previously accumulated at higher temperatures could still exchange with extracellular proline at $0^{\circ}$. At $0^{\circ}$ proline pools of moderate size were stable for at least $3 \mathrm{hr}$. When a stable pool at $0^{\circ}$ was established by exposure to $\mathrm{I}^{\circ} 22 \times \mathrm{IO}^{-7} \mathrm{M}-\mathrm{L}-\left[\mathrm{U}-{ }^{14} \mathrm{C}\right]$ proline (see Methods), the rate of exchange between intracellular and unlabelled extracellular proline was independent of the initial external proline concentration in the range $10^{-7} \mathrm{M}$ to $7.5 \times 10^{-4} \mathrm{M}$. At $10^{\circ}$ the rate of exchange was not markedly dependent on external proline concentration, but the final value of intracellular radioactivity 
observed was concentration-dependent, due to the establishment of a new equilibrium between internal and external proline. Further, when the logarithm of the residual intracellular radioactivity was expressed as a function of time, the exchange process was revealed as an initial rapid phase followed by a period during which exchange was slower (see Britten \& McClure, 1962; Kessel \& Lubin, 1962). These workers interpreted this as indicating the presence of at least two pool components, one capable of rapid exchange with extracellular proline, the other a slowly exchanging component.

Several proline analogues also exchanged with intracellular radioactive proline. A direct correlation was demonstrated between ability of an analogue to inhibit proline uptake in the presence of chloramphenicol (see Table 2) and ability to effect exchange. When tested at $5 \times 10^{-5} \mathrm{M}$ - (based on the concentration of L-isomer), 3,4-dehydro-DLproline, L-azetidine-2-carboxylic acid, L-thiazolidine-4-carboxylic acid and 4-methylene-DL-proline exchanged readily at $10^{\circ}$ with the pool established by prior exposure

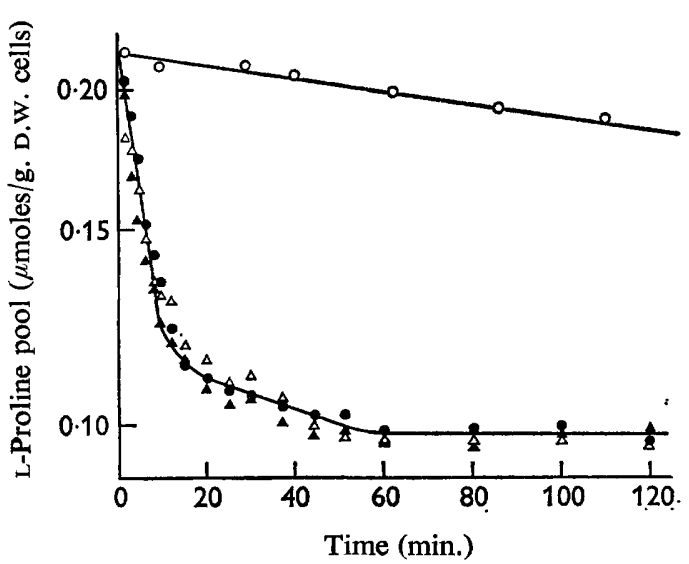

Fig. 6

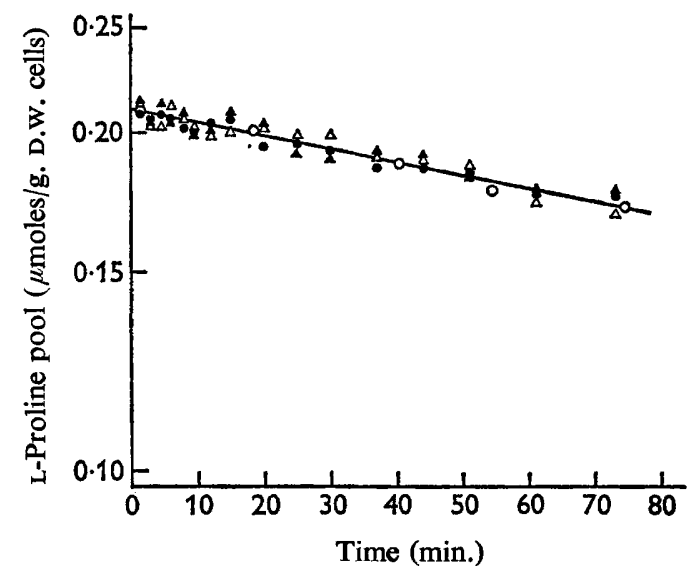

Fig. 7

Fig. 6. Exchange between labelled L-proline in the amino acid pool of Escherichia coli C4 with extracellular 3,4-dehydro-DL-proline, L-azetidine-2-carboxylic acid or (unlabelled) L-proline at $0^{\circ}$. The amino acid pool of bacteria maintained at $25^{\circ}$ in $232 \mathrm{G}$ medium containing chloramphenicol ( $150 \mu \mathrm{g}$. $/ \mathrm{ml}$.) was 'loaded' by exposure to $1 \cdot 22 \times 10^{-7} \mathrm{M}-\mathrm{L}-[\mathrm{U}-14 \mathrm{C}]$ proline ( $130 \mu \mathrm{c} / \mu \mathrm{mole}$ ) for Io min., followed by cooling the bacterial suspension to $0^{\circ}$ and resuspension in fresh $232 \mathrm{G}$ medium containing $150 \mu \mathrm{g}$. chloramphenicol $/ \mathrm{ml}$. Exchange was initiated by adding samples of this bacterial suspension to tubes containing either L-proline, 3,4-dehydro-DL-proline or L-azetidine-2-carboxylic acid solutions to yield final concentrations of $5 \times 10^{-5} \mathrm{M}$ (based on the content of L-isomer). $\mathrm{O}-\mathrm{O}$, Control; $\triangle-\triangle$, L-proline; $\Delta-\mathbf{\Delta}, 3,4$-dehydro-DL-proline; - - , L-azetidine-2-carboxylic acid.

Fig. 7. Exchange between labelled L-proline in the amino acid pool of azetidine-resistant Escherichia coli strain Az642 with extracellular 3,4-dehydro-DL-proline, L-azetidine-2carboxylic acid and unlabelled L-proline at $0^{\circ}$. Details and symbols as described for Fig. 6 , except that, owing to the diminished permease activity of $E$. coli strain Az642, time of 'loading' of the pool at $25^{\circ}$ was extended to $30 \mathrm{~min}$.

to $\mathrm{I} \cdot 22 \times 10^{-7} \mathrm{M}-\mathrm{L}-\left[\mathrm{U}-{ }^{14} \mathrm{C}\right]$ proline. Under the same conditions glycyl-L-proline supported very little exchange, while DL-pipecolic acid, 4,5-dehydro-DL-pipecolic acid, Dproline and D-azetidine-2-carboxylic acid were unable to exchange with intracellular L-proline.

The exchange reaction between accumulated labelled proline and extracellular 3,4- 
dehydroproline or azetidine-2-carboxylic acid was studied in detail at $0^{\circ}$ and $10^{\circ}$. At $0^{\circ}$ not only the rates of exchange but also the final steady state pool values after exchange between a labelled pool (established by exposure to $\mathrm{I} \cdot 22 \times 1 \mathrm{O}^{-7} \mathrm{M}-\mathrm{L}-\left[\mathrm{U}-{ }^{14} \mathrm{C}\right]$ proline) and external L-proline, 3,4-dehydro-DL-proline or L-azetidine-2-carboxylic acid $\left(5 \times 10^{-5} \mathrm{M}\right.$, based on the content of L-isomer) were virtually identical (Fig. 6). At $10^{\circ}$ both analogues exchanged with intracellular labelled proline, but in the presence of L-azetidine-2-carboxylic acid loss of radioactivity from the pool ceased after the first (rapid) phase of exchange. Other experiments, in which the steady-state pool values were measured following simultaneous addition of $\mathrm{I} \cdot 22 \times 1 \mathrm{IO}^{-7} \mathrm{M}-\mathrm{L}-\left[\mathrm{U}-{ }^{14} \mathrm{C}\right]$ proline and L-azetidine-2-carboxylic acid at concentrations ranging from $5 \times 1 \mathrm{IO}^{-5} \mathrm{M}$ to $2.5 \times 10^{-3} \mathrm{M}$, established that this behaviour was due to the preferential re-accumulation of labelled proline molecules which had left the pool by exchange with azetidine. The final pool values found in these experiments were dependent on the

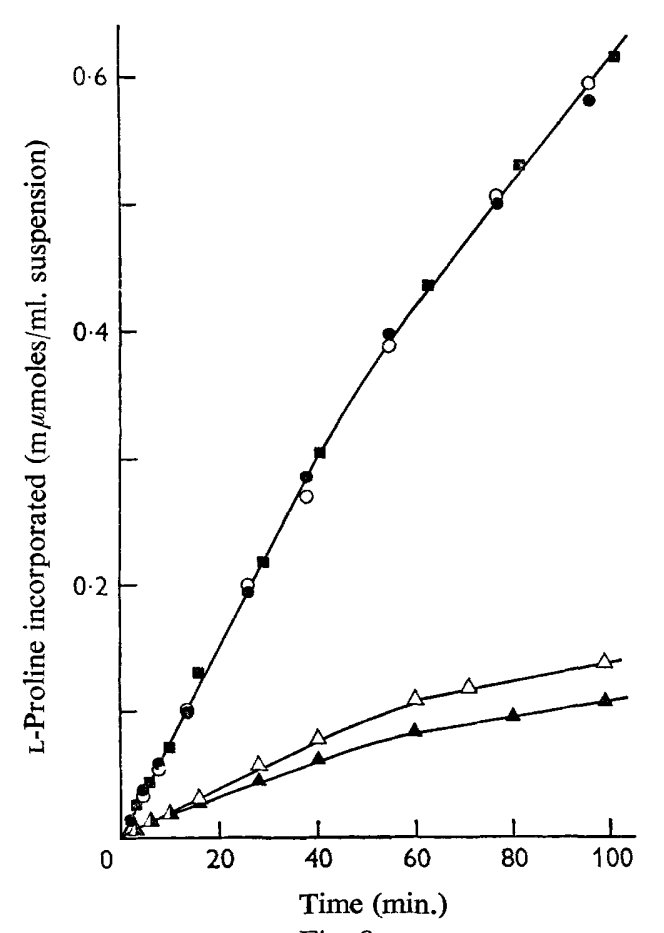

Fig. 8

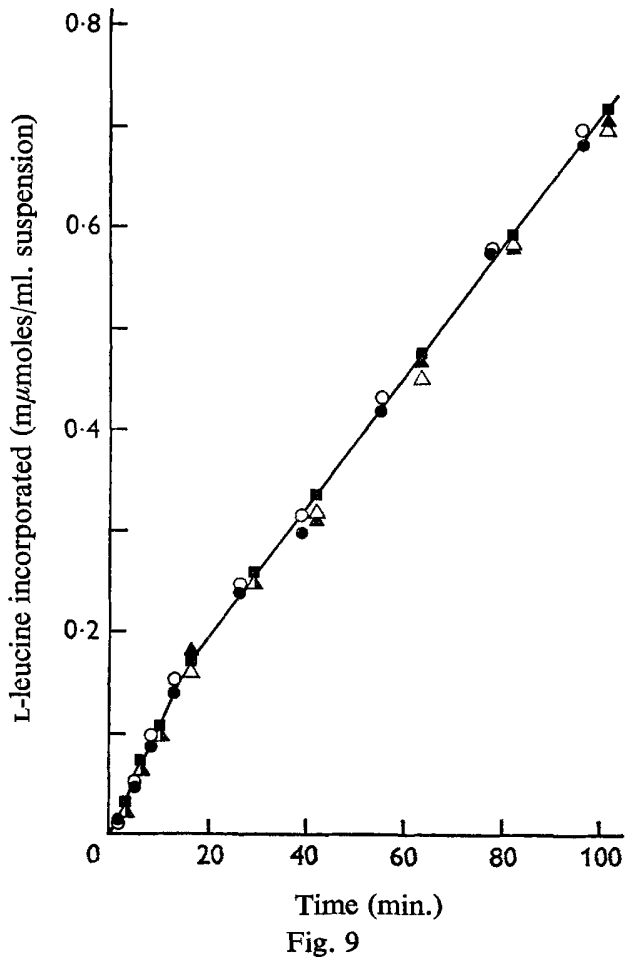

Fig. 9

Fig. 8. Incorporation of labelled L-proline into the trichloroacetic acid-insoluble fraction of Escherichia coli wild-type $\mathrm{C} 4$ and analogue-resistant strains. Cultures growing exponentially at $37^{\circ}$ in $232 \mathrm{G}$ medium were cooled and maintained at $10^{\circ}$ for $2 \mathrm{hr}$. L-[U-14 C]Proline $(3 \mathrm{I} \cdot 25$ $\mu \mathrm{C} / \mu$ mole) and L-leucine were added to give final concentrations of $2 \times 10^{-6} \mathrm{M}$. Samples were withdrawn at intervals for determination of total uptake of labelled proline and radioactivity incorporated into trichloroacetic acid-insoluble material (see Methods). Azetidineresistant strains: - $-\mathrm{Az}_{3} ; \mathrm{O}-\mathrm{O}, \mathrm{Az} 642$. 3,4-Dehydroproline-resistant strains: $\Delta-\mathbf{A}$, DHP 27; $\triangle-\triangle$, DHP 29. -1- strain C4.

Fig. 9. Incorporation of labelled L-leucine into the trichloroacetic acid-insoluble fraction of Escherichia coli wild-type $\mathrm{C}_{4}$ and analogue-resistant strains. Details and symbols as described for Fig. 8, except that $\mathrm{L}-\left[\mathrm{U}-{ }^{14} \mathrm{C}\right]$ leucine $(50 \mu \mathrm{C} / \mu \mathrm{mole})$ and $\mathrm{L}$-proline replaced L-leucine and $\mathrm{L}_{-}\left[\mathrm{U}-{ }^{14} \mathrm{C}\right]$ proline. 
azetidine-2-carboxylic acid concentration and were identical with those observed when the same amounts of azetidine were added to comparable bacterial suspensions in which a pool had previously been established by exposure to $\mathrm{I} \cdot 22 \times 10^{-7} \mathrm{M}-\mathrm{L}-\left[\mathrm{U}-{ }^{14} \mathrm{C}\right]$ proline.

The exchange reaction could not be conveniently studied in many analogue-resistant mutants possessing very low permease activities. An azetidine-resistant strain (Az 642) displaying a diminished permease activity with much reduced affinity for azetidine (see Fig. 5) completely lacked the ability to promote exchange between intracellular radioactive proline and external (unlabelled) proline, 3,4-dehydroproline or azetidine (Fig. 7).

\section{Incorporation of proline and leucine into TCA-insoluble material of analogue-resistant strains}

Compared with the parent strain Escherichia coli $\mathrm{C} 4$, the capacity to incorporate exogenous $\mathrm{L}-\left[\mathrm{U}-{ }^{14} \mathrm{C}\right]$ proline into TCA-insoluble material was markedly decreased in mutants selected for 3,4-dehydroproline resistance (Fig. 8). This diminution in proline incorporation was not due to a decrease in the rate of overall protein synthesis in the mutants, since the rate of incorporation of $\mathrm{L}-\left[\mathrm{U}-{ }^{14} \mathrm{C}\right]$ leucine into protein was identical in both the parent strain and in all the mutants studied (Fig. 9). This suggests that those mutants with a decreased capacity for the uptake of exogenous proline continue to synthesize (unlabelled) proline and preferentially use this endogenous source for synthesis of protein. Although the rate of uptake of proline from the medium was decreased in most of the azetidine-resistant mutants tested, the residual permease activity was still capable of ensuring a sufficient supply of proline for protein synthesis since the rate of incorporation of exogenous labelled proline into protein was identical in the parent strain and in at least two azetidine-resistant mutants (Fig. 8).

\section{DISCUSSION}

Earlier experiments on the proline permease of Escherichia coli strains B and w (Britten \& McClure, 1962; Kessel \& Lubin, 1962) have been confirmed with $E$. coli strain $\mathrm{C} 4$, a derivative of $E$. coli K-IO. The observations were extended to include a study of the specificity of the permease towards proline analogues. Inhibition of proline accumulation by 3,4-dehydroproline and azetidine-2-carboxylic acid, the two analogues studied in detail, was competitive, suggesting that both analogues enter the cell by the mechanism responsible for transport of proline. That 3,4-dehydro-proline and azetidine actually enter the cell is indicated by two types of observation: (i) both analogues are incorporated into the proteins of $E$. coli (Fowden \& Richmond, I963; Fowden et al. 1963); (ii) both analogues exchanged with previously accumulated proline (Fig. 6).

Other analogues capable of inhibiting proline uptake (Table 2) also compete with proline for sites leading to accumulation within the cell. The proline permease of the parent culture displayed affinity for a number of 4-substituted proline derivatives. The analogues cis- and trans-4-chloroprolines are of particular interest since the former inhibited the uptake of proline to about the same extent as azetidine, but the latter possessed far less inhibitory action (Table 2). This is in contrast to the observations of Gottlieb, Fujita, Udenfriend \& Witkop (1965), who showed that incor- 
poration of cis-4-fluoroproline into TCA-insoluble material exceeded that of the trans isomer in a cell-free system from Escherichia coli. Whereas azetidine, the lower homologue of proline, markedly inhibited uptake of proline, the higher homologue, pipecolic acid, was devoid of inhibitory action, an effect presumably attributable to the larger ring structure of the latter compound.

A large number of strains were obtained from Escherichia coli $\mathrm{C}_{4}$ following selection for resistance to the growth-inhibitory analogues 3,4-dehydroproline or azetidine-2carboxylic acid. In general, strains selected for resistance to 3,4-dehydroproline were also resistant to azetidine and failed to incorporate either analogue into protein. Some of these strains displayed impaired ability to take up exogenous proline; others excreted proline, but possessed normal permease activity. In many of the prolineexcreting mutants the accumulation of proline showed anomolous behaviour in that labelled proline passed into the cells, but uptake was followed by rapid loss of radioactivity (see, for example, strain DHP 2 I, Fig. 4). Mutants of this type will be discussed fully in a later publication.

Several workers have shown changes in permeability in mutants selected for resistance to amino acid analogues. Failure of a toxic analogue to enter the cell serves to exclude it from the site (or sites) at which toxicity is exerted and accounts fully for resistance to the analogue. It is commonly found that failure to transport an analogue is accompanied by failure of the corresponding natural amino acid to enter the cell (Schwartz et al. 1959; Ferroluzzi-Ames, 1964; Lester, 1966; Shifrin et al. 1966; see also reviews by Moyed, 1964; Fowden et al. 1967). In the present investigation the impairment of the proline permease in dehydroproline-resistant strains was substantiated by decreased incorporation of exogenous proline into protein (Fig. 8). Presumably 3,4-dehydroproline and azetidine-2-carboxylic acid were excluded from protein by the same mechanism.

Strains selected for resistance to azetidine did not show cross-resistance to 3,4 dehydroproline. In some strains the proline permease was normal; proline excretion, if it occurred at all, was weak. The mechanism of resistance in these strains is under investigation. The majority of the azetidine-resistant strains isolated possessed an impaired capacity for uptake of proline (Fig. 4), though the residual permease activity was sufficient to meet the needs of protein synthesis, at least at $10^{\circ}$ (Fig. 8). The behaviour of these mutants is of interest since growth was inhibited by 3,4-dehydroproline yet they still incorporated this analogue into protein. It was shown that the affinity of the proline permease of one of these strains (AZ 642) for proline and 3,4dehydroproline was comparable with that of the parent strain, but affinity for azetidine was considerably reduced. Thus, strain AZ642 displayed a highly selective effect towards proline analogues, owing its resistance to azetidine to the capacity to exclude this compound from the cell. Other isolates behaved similarly, but it should be noted that the method of selection of azetidine-resistant strains (see Methods) makes it possible that most of these cultures were derived from a single clone and hence genetically identical.

Although in the parent organism affinity of the proline permease for 3,4-dehydroproline was comparable with that for proline itself, its affinity for azetidine was somewhat lower. This difference, however, was not apparent in the exchange of intracellular labelled proline with extracellular (unlabelled) proline or proline analogues. The rates of exchange of proline, 3,4-dehydroproline and azetidine were virtually 
identical (Fig. 6). The azetidine-resistant strain AZ 642 failed to promote the exchange reaction between intracellular proline and extracellular proline, 3,4-dehydroproline or azetidine (Fig. 7). Kessel \& Lubin (1962) described an Escherichia coli mutant lacking proline permease activity which also lacked the capacity to exchange internal and external proline at $0^{\circ}$. They concluded that uptake and exchange are closely related phenomena. The isolation of $\mathrm{AZ} 642$, a strain unable to promote exchange yet possessing a permease which, though impaired, was still capable of proline uptake, suggests that the two processes may not be closely interrelated. Other experiments (Britten \& McClure, I962; Britten, I965) lead to the same conclusion. For example, uptake could not occur at $0^{\circ}$ or in the absence of an energy source, though exchange was rapid under these conditions.

Excretion of proline implies failure of the metabolic control of proline biosynthesis. Proline-excreting dehydroproline-resistant derivatives of Escherichia coli $\mathrm{K}-\mathrm{I} 2$ and azetidine-resistant strains of Salmonella typhimurium SW I06I which excrete proline have also been obtained, but not yet studied in detail (Tristram, unpublished observations). In $E$. coli proline is formed from glutamate, via glutamic $\gamma$-semialdehyde and its spontaneous cyclization product, $\Delta^{\mathbf{1}}$-pyrroline-5-carboxylic acid. The overall conversion of glutamate to $\Delta^{1}$-pyrroline-5-carboxylic acid is inhibited by proline, 3,4-dehydroproline and, to a lesser extent, by azetidine (Strecker, 1957; Baich \& Pierson, 1965; Tristram \& Thurston, 1966). Formation of $\Delta^{1}$-pyrroline-5-carboxylic acid by a proline-excreting 3,4-dehydroproline-resistant mutant had lost its sensitivity to proline (Baich \& Pierson, I965). At least the earlier enzymes of proline biosynthesis are subject to enzyme repression by the final product of the pathway (Tristram \& Thurston, 1966). Preliminary experiments have shown that some of the analogueresistant strains which excrete proline are no longer subject to repression; in others the formation of $\Delta^{1}$-pyrroline-5-carboxylic acid is insensitive to end-product inhibition (Neale \& Tristram, unpublished observations). The genetic study of dehydroprolineand azetidine-resistant strains has commenced and should lead to recognition of proline regulatory genes and also the gene (or genes) determining the proline permease.

One of the authors (S.N.) gratefully acknowledges the receipt of a grant from the British Empire Cancer Campaign.

\section{REFERENCES}

Algranati, I. D. (1963). Determination of initial rates in enzymic non-linear progress reactions. Biochim. biophys. Acta 73, I52.

Baich, A. \& PIERSON, D. J. (1965). Control of proline synthesis in Escherichia coli. Biochim. biophys. Acta I04, 397.

BeERSTeCHer, E. (1950). Bacterial inhibition by a penicillin moiety. Proc. Soc. exp. Biol. Med. 73, 200.

BRITTEN, R. J. (1965). The concentration of small molecules within the microbial cell. Symp. Soc. gen. Microbiol. $15,57$.

Britten, R. J. \& MCClure, F. T. (1962). The amino acid pool in Escherichia coli. Bact. Rev. $26,292$.

CoHen, G. N. \& KePes, A. (1962). Permeation. In The Bacteria; a Treatise on Structure and Function, Ed. by I. C. Gunsalus and R. Y. Stanier, vol. 4, p. I79. New York: Academic Press.

COHEN, G. N. \& MUNIER, R. (1959). Effets des analogues structuraux d'amino acides sur la croissance, la synthèse de protéines et la synthèse d'enzymes chez Escherichia coli. Biochim. biophys. Acta 31, 347.

Dixon, M. \& WebB, E. C. (1964). Enzymes, 2nd ed. London: Longmans.

DReYfuss, J. \& PARdeE, A. B. (1966). Regulation of sulphate transport in Salmonella typhimurium. J. Bact. 9r, 2275. 
Echols, H., Garen, A., Garen, S. \& Torriani, A. M. (I96i). Genetic control of repression of alkaline phosphatase in E. coli. J. molec. Biol. 3, 425.

Ferroluzzi-Ames, G. (1964). Uptake of amino acids by Salmonella typhimurium. Archs Biochem. Biophys. ro4, I.

Fowden, L., Lewis, D. \& Tristram, H. (1967). Toxic amino acids: their action as antimetabolites. Advauc. Enzymol. 29, 89.

Fowden, L., Neale, S. \& Tristram, H. (1963). Effect of 3,4-dehydro-Dl-proline on growth and protein synthesis. Nature, Lond. 199, 35.

FowDEN, L. \& RiCHMOND, M. H. (I963). Replacement of proline by azetidine-2-carboxylic acid during biosynthesis of protein. Biochem. biophys. Acta 7r, 459.

Gottlieb, A. A., Fujita, Y., Udenfriend, S. \& Witkop, B. (1965). Incorporation of cis- and trans4-fluoro-L-prolines into proteins and hydroxylation of the trans isomer during collagen biosynthesis. Biochemistry 4, 2507.

KEMPNER, E. S. \& Cowie, D. B. (I960). Metabolic pools and the utilization of amino acid analogues for protein synthesis. Biochim. biophys. Acta 42, 401 .

Kessel, D. \& LubIN, M. (I962). Transport of proline in Escherichia coli. Biochim. biophys. Acta 57, 32.

LESTER, G. (1966). Genetic control of amino acid permeability in Neurospora crassa. J. Bact. 9I, 677.

Lubin, M., Kessel, D. H., Budreau, A. \& Gross, J. D. (1960). The isolation of bacterial mutants defective in amino acid transport. Biochim. biophys. Acta 42, 535.

MAUGER, A. B. \& WiTkop, B. (I966). Analogues and homologues of proline and hydroxyproline. Chem. Rev. 66, 47.

MoYed, H. S. (1964). Biochemical mechanisms of drug resistance. A. Rev. Microbiol. r8, 347.

MUNIER, R. \& COHEN, G. N. (1959). Incorporation d'analogues structuraux d'aminoacides dans les protéines bactériennes au cours de leur synthèse in vivo. Biochim. biophys. Acta 31, 378 .

NeAle, S. \& Tristram, H. (1963). Effect of $O$-methyl-DL-threonine and $O$-methyl-DL-serine on growth and protein synthesis in Escherichia coli. J. Bact. 86, I24I.

Neale, S. \& Tristram, H. (1964). Incorporation of 3,4-dehydroproline into alkaline phosphatase of E. coli. 6th Int. Cong. Biochem. Abstracts 4, I2I (p. 325).

Neale, S. \& Tristram, H. (1965). Loss of ability to concentrate proline in Escherichia coli: basis of resistance to proline analogues. J. gen. Microbiol. 39, vii.

Peterson, P. J. \& Fowden, L. (I965). Purification, properties and comparative specificities of the enzyme prolyl-transfer ribonucleic acid synthetase from Phaseolus aureus and Polygonatum multiflorum. Biochem. J. 97, I 12.

RICHMOND, M. H. (1962). The effect of amino acid analogues on growth and protein synthesis in microorganisms. Bact. Rev. 26, 398.

Richmond, M. H. (1965). The enzymic basis of specific antibacterial action by structural analogues. Biol. Rev. 40, 93.

Roberts, R. B., Abelson, P. H., Cowie, D. B., Bolton, E. T. \& Britten, R. J. (1955). Studies of biosynthesis in Escherichia coli. Publs Carnegie Instn, no. 607, p. I.

Schwartz, J. H., MaAs, W. K. \& Simon, E. J. (I959). An impaired concentrating mechanism for amino acids in mutants of Escherichia coli resistant to L-canavanine and D-serine. Biochim. biophys. Acta 32, 582 .

Shifrin, S., Ames, B. N. \& Ferroluzzi-Ames, G. (1966). Effect of the $\alpha$-hydrazino analogue of histidine on histidine transport and arginine synthesis. J. biol. Chem. 24I, 3424.

Smith, L. C., Ravel, J. M., Skinner, C. G. \& Shive, W. (1962). 3-4-Dehydroproline, a proline antagonist. Archs Biochem. Biophys. 99, 60.

STRECKER, H. J. (1957). The interconversion of glutamic acid and proline. I. The formation of $\Delta^{\mathbf{1}}$ pyrroline-5-carboxylic acid from glutamic acid in Escherichia coli. J. biol. Chem. 225, 825 .

Tristram, H. (1960). The adaptive degradation of L-histidine by Paracolobactrum aerogenoides. J. gen. Microbiol. 23, 425.

Tristram, H. \& Thurston, C. F. (I966). Control of proline biosynthesis by proline and proline analogues. Nature, Lond. 212, 74.

UNGER, L. \& DeMoss, R. D. (1966). Action of a proline analogue, L-thiazolidine-4-carboxylic acid, in Escherichia coli. J. Bact. 9r, I 556. 